\title{
Aspects of biology of Megalobulimus paranaguensis (Gastropoda, Acavoidea) in the coastal plain of the Brazilian southeast
}

\author{
José H. Fontenelle' \& Marcel S. Miranda ${ }^{2}$
}

1.Parque Zoobotânico Orquidário Municipal de Santos, Praça Washington, s/n, 1 1065-600 Santos, SP, Brasil. (josefontenelle@santos.sp.gov.br)
2. Universidade Estadual de Campinas, Departamento de Biologia Animal, Rua Monteiro Lobato, 255, 13083-970 Campinas, SP, Brasil. (marcelsmiranda@gmail.com)

Received 17 May 2016.

Accepted 14 October 2016

DOI: $10.1590 / 1678-4766 e 2017004$

\begin{abstract}
We studied the reproductive biology of Megalobulimus paranaguensis (Pilsbry \& Ihering, 1900), a large and long-lived land gastropod from the Atlantic Rainforest of Brazil. The study was conducted at an urban park in the city of Santos, state of São Paulo. For 4 years, we counted the egg postures and annual eclosion rate of 32 captive snails and looked for associations between egg posture and the climatical variables of the period. The annual mean posture of 8.7 eggs per snail obtained in our results is a small number, but typical of Brazilian macromollusks. The annual eclosion rate was $31 \%$. The beginning of the annual activity period of snails occurred in the middle of March, and lasted $33.97 \pm 3.02$ weeks. The dormancy period started in the beginning of November, and lasted 18.39 \pm 3.11 weeks. There were two egg posture peaks, a minor peak between March and May, and a major peak between August and November, with greater values in September. Megalobulimus paranaguensis has a well-defined seasonal reproductive pattern influenced by environmental temperature and temperature range. Furthermore, in this snail, reproduction is negatively influenced by temperature increasing and temperature range.
\end{abstract}

KEYWORDS. Aruá-do-mato, egg posture, land snail, Atlantic Rainforest, reproduction.

RESUMO. Aspectos da biologia de Megalobulimus paranaguensis (Gastropoda, Acavoidea) na planície costeira do sudeste brasileiro. Nós estudamos a biologia reprodutiva de Megalobulimus paranaguensis (Pilsbry \& Ihering, 1900), um grande e longevo gastrópode terrestre da Floresta Atlântica na costa sudeste do Brasil, em um parque urbano na cidade de Santos, Estado de São Paulo, ao longo de quatro anos, pelo número de posturas e taxa de eclosão anual de 32 caracóis cativos. Relacionamos estes dados com variáveis climáticas do mesmo período. Obtivemos uma média anual de posturas de 8.7 ovos por caracol, um número baixo, típico da fauna de macromoluscos terrestres brasileiros. A taxa de eclosão anual foi de $31 \%$. O início do período anual de atividade ocorreu em meados de março e dura 33.97 \pm 3.02 semanas; e o início da dormência ocorreu no começo de novembro; com duração de 18.39 \pm 3.11 semanas. Existem dois picos de postura, um menor entre março a maio e um pico maior antes da estivação, entre os meses de agosto a novembro, com maiores valores em setembro. Megalobulimus paranaguensis possui um padrão sazonal reprodutivo bem marcante influenciado pela temperatura do ambiente e amplitude de temperatura. A reprodução é influenciada negativamente pelo aumento da temperatura e da amplitude de temperatura.

PALAVRAS-CHAVE. Aruá-do-mato, posturas de ovos, caracol terrestre, Mata Atlântica, reprodução.

Megalobulimus Miller, 1878, which includes species popularly known as "aruá-do-mato", is a group of giant Neotropical land snails that belong to the subfamily Megalobuliminae (Strophocheilidae) (BoucheT \& RocroI, 2005). The genus has great diversity, with 83 described species, 63 of which occur in Brazil (Simone, 2006, 2012; Borda \& Ramirez, 2013; Fontenelle et al., 2014). Like other land snails, the species of Megalobulimus are nocturnal (BEQUAERT, 1948). During the day, or during dormancy periods, individuals bury themselves in the soil or leaf litter (BEQUAERT, 1948). They are iteroparous hermaphrodite snails with annual periodicity and great longevity, can live up to 35 years (Pinto-DE-Oliveira et al., 1984; Horn et al., 2005; FonTENELLE \& MirANDA, 2012), and generally occur in low densities and irregular distribution (SIMONE, 1999; EsTON et al., 2006; Miranda et al., 2015). Like other Brazilian pulmonates, they have low reproductive potential, spawning 2-5 eggs per batch (Sobreira \& Molina, 2002).

One third of the known species of Megalobulimus in Brazil occur in the coastal plain and mountain ranges parallel to the coast, between the South and Southeast (BEQUAERT, 1948), in the Atlantic Rainforest. This biome is one of the richest in the world in terms of numbers of species, but unfortunately it has been gradually destroyed (MANSUR \& LeME, 1996; Myers et al., 2000). The populations of many species of Megalobulimus from this area, for instance $M$. fragilior (Ihering, 1901), M. parafragilior Leme \& Indrusiak, 1990, M. grandis (Martens, 1885), M. lopesi Leme, 1989, M. proclivis (Martens, 1888) and M. paranaguensis (Pilsbry \& Ihering, 1900), have been reduced, and some may be threatened (LEME, 1989; LEME \& INDRUSIAK, 1990; MANSUR \& Leme, 1996; Fischer \& Colley, 2005; Miranda et al., 
2015). Officially, the Brazilian authorities only list one species of Megalobulimus in their list of threatened species, $M$. cardosoi (Morretes, 1952), which is endemic to the state of Alagoas, and is critically endangered (SANTOS et al., 2015).

Megalobulimus paranaguensis (Pilsbry \& Ihering, 1900) was described from the city of Paranaguá (state of Paraná), and is distributed in the coastal plain of the Atlantic Rainforest, between Guaratuba, state of Paraná, and Itanhaém, state of São Paulo (Morretes, 1954). There have been records also between the Island of São Vicente, state of São Paulo (Miranda et al., 2015) and the northern coast of the state of Santa Catarina (AGUDO-PADron, 2014), coinciding with a geomorphology characterized by large coastal plains between Serra do Mar, and long beaches interspersed by estuaries (MueHE, 1998). After the introduction of the alien snail Achatina fulica Bowdich, 1822 many individuals of M. paranaguensis have been accidentally killed in control campaigns (COLLEY \& FisCHER, 2009).

Recently, aspects of the ecology and distribution of some species of Megalobulimus were studied in more detail (Beltramino, 2013, 2014; Beltramino et al., 2015; Miranda et al., 2015; Miranda \& Fontenelle, 2015; MIRANDA \& PECORA, 2016), providing important information about their biology and conservation. On the other hand, data about the reproductive biology of Megalobulimus species are still scarce, and restricted to the studies of PINTO-DEOliveIra et al. (1984), on Megalobulimus bronni (Pfeiffer, 1847), Sobreira \& Molina (2002), on Megalobulimus aff. gummatus (Hidalgo, 1870) and Horn et al. (2005), on Megalobulimus abbreviatus (Bequaert, 1948). Information obtained by these studies have increased our knowledge of their ecology and can be used to develop conservation and management plans for Megalobulimus spp. The objective of this study was to analyze the activity and oviposition of captive M. paranaguensis at Parque Zoobotânico Orquidário Municipal, and to evaluate which environmental variables affect this pattern.

\section{MATERIAL AND METHODS}

This study took place at "Parque Zoobotânico Orquidário Municipal de Santos" (PZOMS), a small 22,000 $\mathrm{m}^{2}$ park located in the municipality of Santos (UTM: 23K E $362672.57,7348904.53 \mathrm{~N})$. PZOMS presents flat topography, arboreal phytophysiognomy with understory formation and litter accumulation. Its area is fragmented, and has malls, animal enclosures, a 4,300 $\mathrm{m}^{2}$ lake and rainwater drainage channels.

Between January 2007 to December 2010, 32 individuals of $M$. paranaguensis were captured at the PZOMS, kept captive in boxes and placed in the shade, in understory areas at the park. The boxes were $50 \times 80 \times 80 \mathrm{~cm}$ and had a 0.5 inch screen. Four snails were maintained in each box, which was lined with substrate containing $15 \mathrm{~cm}$ of soil + sand and $10 \mathrm{~cm}$ of leaf litter. Food was provided ad libitum and it was similar to what is consumed by the free population of the PZOMS, consisting of Malvaviscus, Spathiphyllum,
Piper and "jurubeba" (Solanum paniculatum). The leaf litter level was completed weekly, litter was changed monthly and the number of postures (eggs/individual) was counted once a month and divided by the number os specimens in each box. Each egg ovoposed were measured $(n=255)$ in length and width. For the years of 2009 and 2010, the annual eclosion rate were obtained. Voucher specimens of the population studied are deposited in the mollusk collection of the Museu de Zoologia da Universidade de São Paulo (lot MZSP 54629). In addition, the beginning and length of activity and dormancy periods of each snail were monitored. The following environmental variables were obtained for the duration of the experiment, from the website http://www. ciiagro.sp.gov.br/ciiagroonline/\#Monitoramento (maintained by EMBRAPA - Agronomic Institute of Campinas) for the municipality of Santos, SP: mean temperature, potential evapotranspiration, number of rainy days, precipitation and temperature range. The temperature range values were obtained by subtracting the mean minimum temperature from the mean maximum temperature from January 2007 to December 2010. A stepwise regression, using AICc as the variable selection criterion between environmental variables and number of postures, was used to evaluate which variables influenced the number of postures. In the results, we only show the environmental variables that have affected the number of postures.

\section{RESULTS AND DISCUSSION}

We observed the beginning of the annual activity period in the mid-March, lasting 33.97 \pm 3.02 weeks; and the beginning of dormancy in the beginning of November, lasting $18.39 \pm 3.11$ weeks in captive individuals. The annual mean egg posture was 8.7 eggs per snail. There were two egg posture peaks, a minor peak between March to May, and a major peak between August and November, with greater values in September (Fig. 1). The annual eclosion were 31\% for both years analysed. The eggs are white, calcareous, elliptical, and are $26.3 \pm 1.82 \mathrm{~mm}$ length per $20.1 \pm 1.16 \mathrm{~mm}$ width (Fig. 2). They are partially buried in litter. At birth,

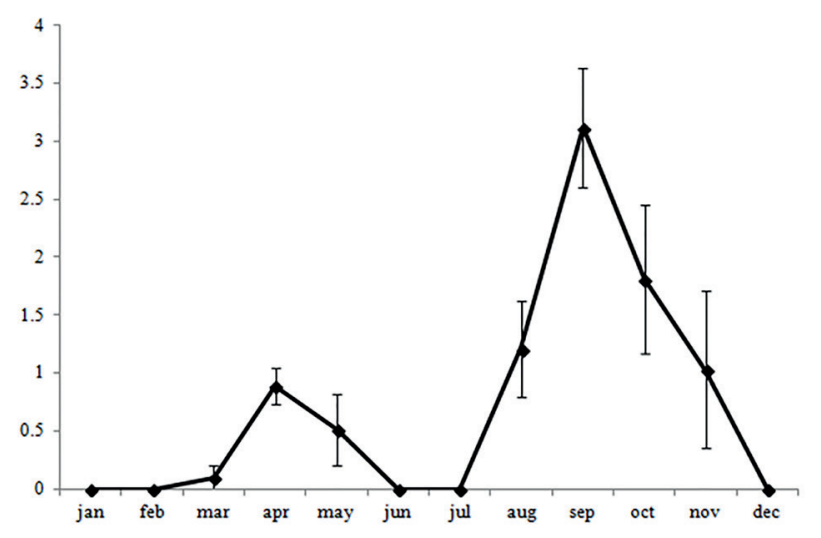

Fig. 1. Mean number of postures of Megalobulimus paranaguensis (Pilsbry \& Ihering, 1900) in Parque Zoobotânico Orquidário Municipal de Santos (PZOMS). 
newly-born individual sometimes eat the eggs from which they have hatched.

Mean temperature values were greater during summer months (from November to February) and lowest in winter months (from May to August), and these fluctuations were well marked during the year (Fig. 3). The temperature range presented greater values in February, June and July, and minor values in May, September and October (Fig. 4). The stepwise regression mainted the variables mean temperature and temperature range in the model. The stepwise regression revealed that mean temperature and temperature range are negatively correlated with both variables (mean temperature: $t=1.93, \mathrm{p}=0.05, \mathrm{~b}=-0.10$; temperature range: $t=2.41$, $\mathrm{p}-0.01, \mathrm{~b}=-0.30)$.

Megalobulimus paranaguensis has a well-marked seasonal reproductive pattern, influenced by temperature and temperature range. The number of postures decrease with increasing temperatures. Gомот (1990) showed that an increase in temperature, related with photoperiod variations, reduces the number of weeks in the reproductive cycle of Helix pomatia Linnaeus, 1758. The abundance and activity of $M$. paranaguensis are influenced by humidity and evapotranspiration in the environment (MIRANDA \& Fontenelle, 2015; MirANDA et al., 2015), which indicate that an increase in the temperature and temperature range result in decreased activity of individuals and, consequently, a decrease in egg production.

Generally, gastropods react to changes in environmental conditions, but also have a circadian cycle and seasonal behavior synchronized by an endogenous biological clock, which anticipate variations in temperature, water and light throughout the year (LAZARIDOU-DIMITRIADOU \& SAUNDERS, 1986; Iglesias et al., 1996). Their characteristic dormancy during the summer months, called aestivation, happens when it is hot or dry (Boss, 1974). The main function of this dormancy, which is very common among land and freshwater mollusks, is to limit water loss by evaporation (CÁCERES, 1997). In M. paranaguensis, aestivation occurs in response to an increase in evapotranspiration (MIRANDA \& FONTENELLE, 2015) and decrease in humidity (MiRANDA et al., 2015) between November and March, which increases water loss to the environment.

The number of postures of $M$. paranaguensis confirms the observation of MiRANDA \& FonTENELle (2015) that this species is iteroparous. Their study was based on markrecapture estimates, and spawning peaks in their data coincided with the activity and recruitment peaks obtained by Miranda et al. (2015) and Miranda \& Fontenelle (2015) for the same species. The iteroparous pattern also occurs in M. abbreviatus (HoRn et al., 2005), which indicates that this must be a pattern in the genus. Moreover, the presence of aestivation and a period with no reproductive activity is a characteristic of $M$. paranaguensis that differs from $M$. abbreviatus, and it is more similar to the patterns of temperate zone species (BAILEY, 1981).

Megalobulimus paranaguensis has low egg production, a pattern that is common in other Brazilian

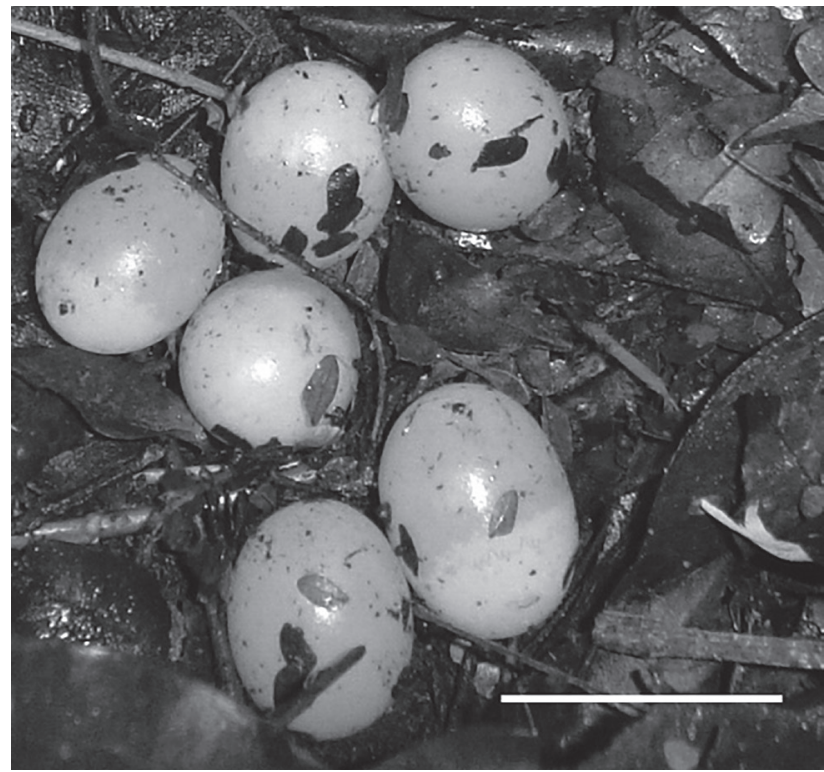

Fig. 2. Egg posture of Megalobulimus paranaguensis (Pilsbry \& Ihering, 1900) in leaf litter (1b). Scale $=30 \mathrm{~mm}$.

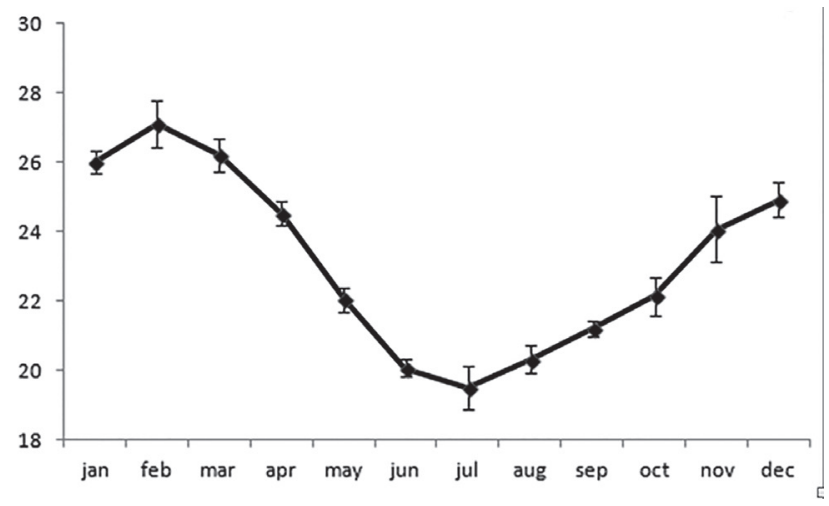

Fig. 3. Seasonal variation of mean temperature per month in municipality of Santos during period sampled.

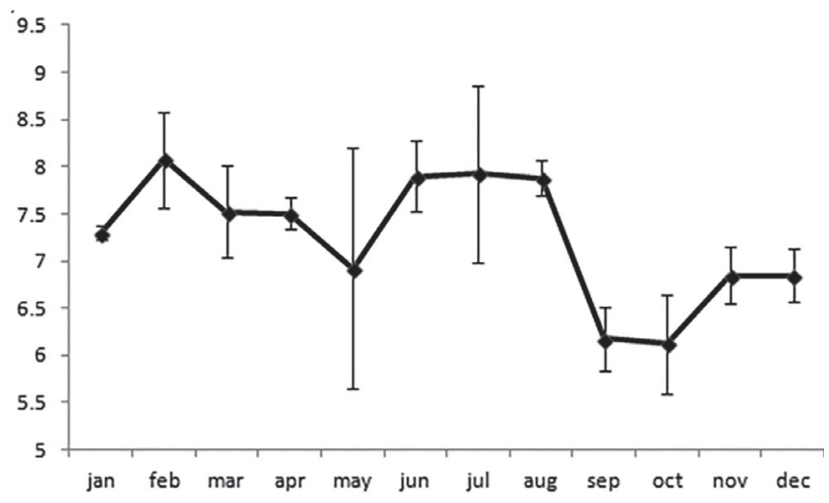

Fig. 4. Seasonal variation of temperature range per month in municipality of Santos during period sampled.

land snails. JURBERG et al. (1988) reported between 10 to 12 eggs per batch in Thaumasthus taunaisii (Ferrusac, 1822). Within Megalobulimus, 1.44 eggs per batch were recorded for Megalobulimus aff. ovatus (Müller, 1774), 2.87 eggs per 
batch for Megalobulimus sp. and 3.71 eggs per batch for $M$. gummatus (Sobreira \& Molina, 2002; Rios et al., 2004). The first behavior performed by newly-born individuals is to eat the egg case. This behavior is important because the shell of young individuals is rather fragile (JURBERG et al., 1988), and calcium is a limiting element for mollusk survivor, being absorbed by the diet and by animal foot sole (FourNiER \& ChÉTAIL, 1984).

The eclosion rate found in our study was low, when compared with another species in literature for another species of genus. SOBREIRA \& Molina (2002) found 52.4\% eclosion rate for Megalobulimus gummatus (Hidalgo, 1870). Rios et al. (2004) found for Megalobulimus aff. ovatus (Muller, 1774) and eclosion rate of $57.9 \%$ for specimens introduced at $t$ the Zoological Park of São Paulo, and for F1 generation it was found $34.5 \%$ eclosion rate of egg obtained by cross fertilization and $28.6 \%$ of the eggs obtained by self-fertilization.

Egg posture peaks in M. paranaguensis occur in the same period as the activity pattern recorded by MIRANDA \& FONTENELLE (2015) in natural conditions and same period, but in a reverse way: when there is a major activity peak, egg laying slows down. This pattern indicates a major reproductive activity period, when energy is allocated for reproduction, decreasing the activity of individuals. An interesting characteristic of the egg posture cycle of $M$. paranaguensis in the study area is that the major peaks occur right before the aestivation period, which occurs between November and March (Miranda et al., 2015; MiRANDA \& Fontenelle, 2015). In Megalobulimus bronni (Pfeiffer, 1847) from Juiz de Fora (state of Minas Gerais), three egg posture peaks were recorded, a major peak between December and February, followed by a second pre-aestivation peak between April and May, and a post-aestivation peak in September. This differs from the pattern of $M$. paranaguensis due to environmental differences between both areas. The major peaks in the end of the year can be explained by the major photoperiod in summer months, which increases egg production in pulmonates (GOMOT-DE-VAUFLEURY, 2001). Moreover, the young individuals that are born in this period generally aestivate and die because they do not have sufficient energy reserves. In general, in newer cohorts there are high mortality rates (HeLler, 2001), which can be more than 94\% in M. mogianensis Simone \& Leme, 1998 (RoMERo, 2004). The occurrence of this egg laying pattern can be an important factor in the mortality rate of wildlife populations.

In this paper, we concluded that $M$. paranaguensis has a well marked seasonal pattern of activity and oviposition. This pattern also directly influendes the surviovorship and activity and juveniles, and can generate a high mortality in younger conhorts.

\section{REFERENCES}

Agudo-Padron, A. I. 2014. Inventario sistemático de los moluscos continentales ocurrentes en el Estado de Santa Catarina, Brasil. Bioma 2:6-23.
BAIley, S. E. R. 1981. Circannual and circadian rhythms in the snail Helix aspersa Müller and the photoperiodic controlof annual activity and reproduction. Journal of Comparative Physiology 142:89-94.

Beltramino, A. A. 2013. Distribution of Megalobulimus sanctipauli (Ihering and Pilsbry, 1900) (Gastropoda: Megalobulimidae) in South America. CheckList 9:469-471.

Beltramino, A. A. 2014. Distribución histórica y área de distribución potencial del megamolusco terrestre Megalobulimus lorentzianus (Doering, 1876) (Gastropoda: Pulmonata) en américa del sur. Boletín de la Asociación Argentina de Malacología 4:10-13.

Beltramino, A. A.; Vogler, R. E.; Gutiérrez-Gregoric, D. E. \& Rumi, A. 2015. Impact of climate change on the distribution of a giant land snail from South America: predicting future trends for setting conservation priorities on native malacofauna. Climatic Change 131:621-633. Doi: 10.1007/s10584-015-1405-3.

Bequaert, J. C. 1948. Monograph of the family Strophocheilidae, a Neotropical family of terrestrial mollusks. Bulletin of Museum of Comparative Zoology of Harvard 100:1-210.

Borda, V. \& Ramirez, R. 2013. Re-characterization of the Red-lip Megalobulimus (Gastropoda: Strophocheilidae) from Peru with description of a new species. Zoologia 30:675-691. DOI: 10.1590/ S1984-46702013005000008.

Boss, K. J. 1974. Oblomovism in the Mollusca. Transactions of American Microscopical Society 93:460-481.

Bouchet, P. \& Rocroi, J. P. 2005. Classification and Nomenclature of Gastropod Families. Malacologia 47:1-397.

CÁCERES, C. E. 1997. Dormancy in Invertebrates. Invertebrate Biology 116:371-383.

Colley, E. \& Fischer, M. L. 2009. Avaliação dos problemas enfrentados no manejo do caramujo gigante africano Achatina fulica (Gastropoda, Pulmonata) no Brasil. Zoologia 26:674-683.

Eston, M. R.; Menezes, G. V.; Antunes, A. Z.; Santos, A. S. R. \& Santos, A. M. R. 2006. Espécie invasora em unidade de conservação: Achatina fulica (Bowdich, 1822) no Parque Estadual Carlos Botelho Sete Barras, SP, Brasil. Revista do Instituto Florestal 18:173-179.

Fischer, M. L. \& Colley E. 2005. Espécie invasora em reservas naturais: caracterização da população de Achatina fulica Bowdich, 1822 (Mollusca - Achatinidae) na ilha Rasa, Guaraqueçaba, Paraná, Brasil. Biota Neotropica 5:127-144.

Fontenelle, J. H.; Cavallari, D. C. \& Simone, L. R. L. 2014. A new species of Megalobulimus (Gastropoda, Strophocheilidae) from Brazilian shell mounds. Strombus 21:30-37.

Fontenelle, J. H. \& Miranda, M. S. 2012. The use of outer lip in age estimation of Megalobulimus paranaguensis (Gastropoda, Pulmonata). Strombus 19:15-22.

Fournier, J. \& ChÉTAIL, M. 1984. Calcium dynamics in land gastropods. American Zoologist 24:857-870.

Gомот, A. 1990. Photoperiod and temperature interaction in the determination of reproduction of the edible snail, Helix pomatia. Journal of Reproduction and Fertility 90:581-585.

Gomot-De-VAufleury, A. 2001. Regulation of growth and reproduction. In: BARKer, G. M. ed. The biology of terrestrial molluscs. Wallingford, CABI Publishing, p. 331-355.

Heller, J. 2001. Life History Strategies. In: Barker, G. M. ed. The Biology of terrestrial molluses. New York, CABI Publishing, p. 413-446.

Horn, A. C. M.; Achaval, M. \& Zancan, D. M. 2005. The annual reproductive cycle of the snail Megalobulimus abbreviatus (Bequaert, 1948) (Gastropoda, Pulmonata). Brazilian Journal of Biology 65:459467.

Iglesias, J; SANTOS, M. \& CASTILlejo, J. 1996. Annual activity cycles of the land snail Helix aspersa Muller in natural populations of north-western Spain. Journal of Molluscan Studies 62:495-505.

Jurberg, P.; Barros, H. M.; Gomes, L. A. L. \& Coelho, A. C. S. 1988. Superfamília Bulimuloidea do Brasil. Bulimulidae: Thaumastus (Thaumastus) taunaisii (Férussac, 1822), com dados biológicos e aspectos comportamentais (Mollusca, Gastropoda, Pulmonata). Boletim do Museu Nacional (Zoologia) 358:1-47.

LaZaridou-Dimitriadou, M. \& Saunders, D. S. 1986. The influence of humity, photoperiod and temperature on the dormancy and activity of Helix lucorum L. (Gastropoda, Pulmonata). Journal of Molluscan Studies 52:180-189. 
Leme, J. L. M. 1989. Megalobulimus lopesi sp. n., uma nova espécie de Pulmonata terrestre da mata atlântica brasileira (Mollusca, Gastropoda, Megalobulimidae). Memórias do Instituto Oswaldo Cruz 84:313-318.

LEME, J. L. M. \& INDRUSIAK, L. F. 1990. Megalobulimus parafragilior, sp. n., uma nova espécie de Pulmonata terrestre da Serra do Mar (Gastropoda, Megalobulimidae). Papéis Avulsos de Zoologia 37:97-105.

Mansur, M. C. D. \& Leme, J. L. M. 1996. The endangered giant Megalobulimus from the Atlantic forest of Brasil. Tentacle 6:14-15.

Miranda, M. S. \& Fontenelle, J. H. 2015. Population dynamics of Megalobulimus paranaguensis in the Brazilian southeast coast. Zoologia 32:463-468. Doi: 10.1590/S1984-46702015000600005.

Miranda, M. S.; Fontenelle, J. H. \& Pecora, I. L. 2015. Population structure of a native and an alien species of snail in an urban fragment of Atlantic Rainforest. Journal of Natural History 49:19-35. Doi: 10.1080/00222933.2014.930756.

Miranda, M. S. \& Pecora, I. L. 2016. Conservation implications of behavioural interactions between the giant african snail and a Brazilian native species. Ethology, Ecology \& Evolution 29:1-9. Doi: 10.1080/03949370.2015.1125951.

Morretes, F. L. 1954. Sôbre Megalobulimus paranaguensis Pilsbry \& Ihering. Arquivos do Museu Paranaense 10:343-344.

MueHE, D. 1998. O litoral brasileiro e sua compartimentação. In: CunHA, S. B. \& Guerra, A. J. T. eds. Geomorfologia do Brasil. São Paulo, Bertrand, p. 273-349.

Myers, N.; Mittermeier, R. A.; Mittermeier, C. G.; Fonseca, G. A. B. \& KENT, J. 2000. Biodiversity hotspots for conservation priorities. Nature 403:853-858.

Pinto-de-Oliveira, M.; Rezende, G. J. R. \& Castro, G. A. 1984. Megalobulimus (Phaiopharus) granulosus Rang, 1831 (Gastropoda,
Pulmonata, Stylommatophora, Strophocheilidae). Comunicações Malacológicas 15:1-18.

Rios, F. R.; Jacinavicius, F. C. \& Molina, F. B. 2004. Taxa de eclosão em ovos de Megalobulimus aff. ovatus (Gastropoda, Pulmonata, Megalobulimidae) incubados em laboratório. Arquivos do Instituto Biológico 71:388-390.

Romero, S. M. B. 2004. Growth of Megalobulimus mogianensis (Gastropoda: Megalobulimidae) raised in laboratory from hatching to adulthood. American Malacological Bulletin 18:79-85.

Santos, S. B.;,Miyahira, I. C.; Salgado, N. C.; Heydrich, I.; Pena, M. S.; Colley, E.; Fernandez, M. A.; Thiengo, S. C.; Gomes, S. R.; Silva, M. J. M.; Gonçalves, I. C.B.; Lacerda, L. E. M.; Tallarico, L. F. \& Martins, D. S. 2015.Observations on the review of the list of endangered non-marine molluscs of Brazil. Tentacle 23:26-28.

Simone, L. R. L. 1999. Gastropoda terrestres. In: Brandẽo, C. R. F. \& Cancello, E. M. eds. Biodiversidade do estado de São Paulo: Uma síntese do conhecimento ao final do século XX. Vol.5. Invertebrados terrestres. São Paulo, FAPESP, p. 3-8.

Simone, L. R. L. 2006. Land and freshwater molluscs of Brazil. São Paulo, EGB, Fapesp. 390p.

Simone, L. R. L. 2012. Taxonomical study on a sample of pulmonates from Santa Maria da Vitória, Bahia, Brazil, with description of a new genus and four new species (Mollusca: Orthalicidae and Megalobulimidae). Papéis Avulsos de Zoologia 52:431-439.

Sobreira, H. B. \& Molina, F. B. 2002. Observações preliminares sobre a biologia reprodutiva de Megalobulimus gummatus (Mollusca, Megalobulimidae) em laboratório. Arquivos do Instituto Biológico 69:139-141. 